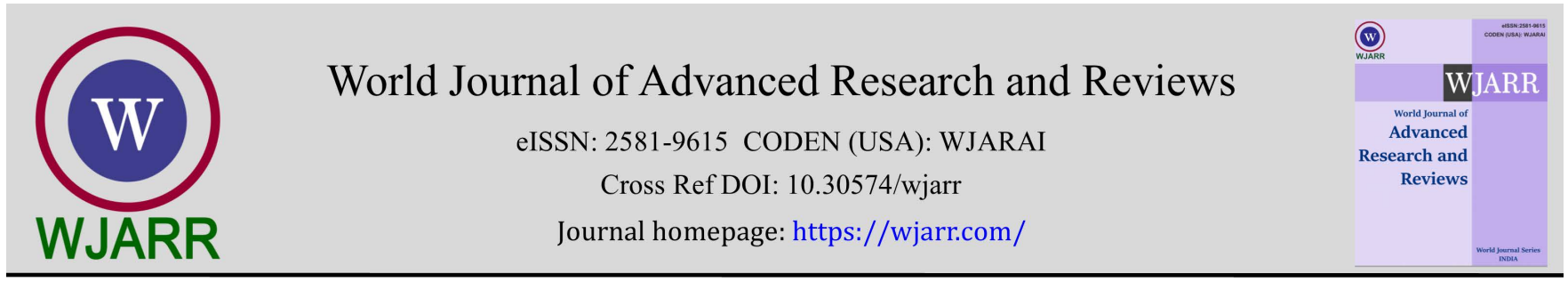

(RESEARCH ARTiClE)

Check for updates

\title{
Population dynamics and parasitism rate of leafhopper species (Hemiptera: Cicadellidae) in maize (Zea mays L.) crop
}

\author{
Atilla Atmaca, Mehmet Mamay and Çetin Mutlu* \\ Department of Plant Protection, Faculty of Agriculture, Harran University, Şanlıurfa 63050, Turkey.
}

World Journal of Advanced Research and Reviews, 2021, 12(02), 448-457

Publication history: Received on 13 October 2021; revised on 17 November 2021; accepted on 19 November 2021

Article DOI: https://doi.org/10.30574/wjarr.2021.12.2.0609

\begin{abstract}
Maize is an important crop in Turkey that is infested by various leafhopper species during the whole season. Monitoring population dynamics and parasitism rate of these species would help to devise effective management practices. This study determined population dynamics of four leafhopper species, i.e., Zyginidia sohrab Zachvatkin, 1947, Empoasca decipiens Paoli, 1930 and Psammotettix striatus (Linnaeus, 1758) in second maize crop. Similarly, population dynamics and parasitism rate of egg parasitoid (Anagrus atomus) of these leafhopper species was also studied through July to November 2018 in Akçakale, Harran and Haliliye districts of Şanlıurfa province, Turkey. Population density of all species significantly varied among studied districts with the highest density of $A$. atomus recorded on 7 September with 30 adults/trap in Haliliye district. The parasitism rate on Z. sohrab eggs was 78\% in Akçakale, $82 \%$ in Harran and $63 \%$ in Haliliye district. It was followed by E. decipiens with $18 \%$ in Akçakale, $14 \%$ in Harran and $32 \%$ in Haliliye. The highest population density of $Z$. sohrab was recorded on 21 September in Akçakale (4328 adults/trap), Harran (3920 adults/trap) and Haliliye (4592 adults/trap). Similarly, E. decipiens had the highest (1216 adults/trap) population density on 10 August in Harran, 12 October (368 adult/trap) in Akçakale and 17 August (2184 adults/trap) in Haliliye. Population dynamics of leafhoppers and their egg parasitoid coincided with each other. The parasitism rate was lower than other provinces in Turkey which is owed to high pesticide use in Şanlıurfa province. Therefore, chemical control should be decided by considering population development of beneficial insect species.
\end{abstract}

Keywords: Zyginidia sohrab; Anagrus atomus; Population monitoring; Sticky trap; Corn

\section{Introduction}

Maize (Zea mays L.) is one of the most important crops contributing towards human and animal nutrition around the world as well as in Turkey. It occupies third position in term of production after wheat and barley in Turkey [1]. Numerous insect species, i.e., Mediterranean corn borer (Sesamia nonagrioides), European corn borer (Ostrinia nubilalis) and leafhoppers are known to infest maize grown as second crop [2]. Zyginidia sohrab Zachvatkin is considered as a serious pest of second crop maize $[3,4,5,6,7,8,9]$. The insect has attracted increased attention since early 2000 's in maize, particularly the one grown as second crop in Turkey. Leafhoppers' damage has been reported on maize from some part of Anatolia region of Turkey [10,11]. Zyginidia sohrab is the main pest of maize crop in Turkey and its population density has been significantly increased since last two decades. It has become the only dominant leafhopper species with $>90 \%$ frequency of occurrence in maize production areas of the country. Empoasca decipiens (Paoli), Asymmetrasca decedens (Paoli), and Psammotettix striatus (Linnaeus 1758) are other leafhopper species infesting maize crop $(<10 \%$ frequency of occurrence) in Turkey [6,8]. Empoasca decipiens is a polyphagous species and economically serious pest in many parts of the world. Psammotettix striatus is a serious pest of wheat and maize crops in Turkey $[6,12]$. Moreover, it serves as a vector of wheat blue dwarf (WBD) phytoplasma [13]. Besides Asymmetrasca decedens also infests maize and wheat crops; it serves as a disease vector of Candidatus Phytoplasma phoenicium in maize [14].

\footnotetext{
${ }^{*}$ Corresponding author: Çetin Mutlu

Department of Plant Protection, Faculty of Agriculture, Harran University, Şanlıurfa 63050, Turkey.

Copyright (C) 2021 Author(s) retain the copyright of this article. This article is published under the terms of the Creative Commons Attribution Liscense 4.0
} 
The biology of Z. sohrab has been extensively studied by Mutlu and Sertkaya [10]. They reported five generations of the species per year in southeastern Anatolia region and number of adults of the species on yellow sticky traps in the second crop maize were eight time higher than main crop maize. Leafhopper adults and nymphs mainly feed on the ventral surface of the leaf and cause direct damage to the plant by sucking bottom leaves [8]. The sucking and puncturing by leafhoppers result in shrinking, browning and ultimately death of primary bottom leaves exposed to the pests. The infected leaves turn to stripe-like purplish color which ultimately turn brown $[4,8]$. The drying of these leaves exert heavy economic loses in maize yield. Heavy infestation of leafhoppers causes complete drying of maize plants -a condition commonly known as "hopper-burn" [15,16].

Mymarid egg parasitoid (Anagrus atomus) is the most important antagonist species of maize leafhoppers [9]. It is a cosmopolitan egg parasitoid of different leafhopper species observed under diverse environmental conditions $[17,18,19]$. The parasitism rate of $A$. atomus has been recorded between $50.2 \%$ and $93.7 \%$ in maize crop grown in southeastern Anatolia region of Turkey [9]. Similarly, the parasitism rate of the species in Italy has been reported between $50 \%$ [20,21]. Likewise, the parasitism rate of the species was $50-80 \%$ in Germany [18].

Monitoring seasonal occurrence/dynamics of insect pests is of fundamental importance in effective pest management $[22,23]$. Assessing peak occurrence time of pest species significantly contributes towards pest management strategies [24]. Forecasting/determining the peak occurrence time of pest species helps to inform producers regarding the most effective time for pest management [23]. Several monitoring methods (i.e., color sticky traps, pheromone traps, and light traps etc.) are used for pest management $[25,22,26]$. The use/choice of these traps depends on insect and plant/crop species. Yellow sticky traps attract flying insects, especially those belonging to Hemiptera order $[25,18,27,28]$. Due to the reason, these traps are used to monitor and control/manage sucking pests in greenhouses and field conditions. However, the effect of these traps on the attraction/trapping of predators and parasitoids in maize crop is unclear. Therefore, the efficacy of these traps in attracting predators and parasitoids needs to be determined. Yellow sticky may exert negative effects on maize ecosystem by trapping natural enemies, especially egg parasitoids of harmful pest species. Keeping in view, this study was conducted to determine the population dynamics of the four leafhopper species and their egg parasitoid in second crop maize grown in different districts of Şanliurfa province, Turkey. It was hypothesized that studied districts will differ in the infestation/density of leafhopper species. It was further hypothesized that yellow sticky traps will significantly attract egg parasitoid species of leafhopper species infesting maize crop. The results of this study would provide empirical information regarding the peak infestation time of leafhopper species. Accordingly, the optimum management time for leafhopper species could be determined based on the results of current study.

\section{Material and methods}

\subsection{Study area}

The current study was conducted in farmer fields in Harran plain, Şanlıurfa province, Turkey (36 $52^{\prime} 39.0^{\prime \prime} \mathrm{N}$, $39^{\circ} 02^{\prime} 02.0^{\prime E} \mathrm{E}$ 400-450 m elevation). Harran plain has approximately 150.000 hectares irrigated area in recent years [29]. Mostly cotton and two different maize crop (main and second) are produced in the Harran plains.

\subsection{Population dynamics of leafhopper species and their egg parasitoid}

The experiment to determine population dynamics of leafhopper species and their parasitoid was conducted in second crop maize fields situated in Akçakale (36.773424 ${ }^{\circ} \mathrm{N}, 38.955222^{\circ} \mathrm{E}$ ), Harran (36.898083 ${ }^{\circ} \mathrm{N}, 38.964500^{\circ} \mathrm{E}$ ) and Haliliye $\left(37.154583^{\circ} \mathrm{N}, 39.403722^{\circ} \mathrm{E}\right)$ district in Şanlıurfa. Population dynamics of four leafhopper species, i.e., Zyginida sohrab, Empoasca decipiens, Assymetrasca decedens and Psammotettix striatus was monitored by yellow sticky traps. Plexiglass yellow sticky traps $(20 \times 25 \mathrm{~cm})$ were coated with sticky polymers (Tangle-Trap Insect Trap Coating; The Tanglefoot Company, Grand Rapids, MI, USA) on both sides, and attached vertically to an iron rod, which was fixed in the ground. Three yellow sticky traps were fixed in each field (during two-four leaf stage of maize plants) 10 meter inside from the field edge to avoid the border effect. The traps were adjusted to plant height weekly by lifting the iron rod in upward direction. The traps were replaced weekly, and the number of leafhopper adults trapped on both sides of traps were counted. Empoasca decipiens and A. decedens were difficult to identify; hence, these were counted together and interpreted as E. decipiens $+A$. decedens complex in the traps counts. The field study lasted from July to November in 2018.

Likewise, population dynamics of $A$. atomus (egg parasitoids of studied leafhopper species) was monitored weekly on yellow sticky traps in the same maize fields. The sticky traps were carefully examined for the presence of $A$. atomus under Floor Standing Magnifier (20 X). 


\subsection{Parasitism rate of Anagrus atomus}

Leaf samples were collected weekly from maize fields to evaluate the parasitism rate of $A$. atomus. Three leaves infested with leafhoppers eggs were collected from 5 random places in the field making 15 leaves form each field during every week. The leaves were collected from bottom, middle and upper parts of maize plants from each location within the field. A total 45 leaves were collected from three fields during each sampling. Since leafhoppers eggs are laid under leaf surface, these are difficult to detect with naked eye [8]. Hence, collected leaves were placed in 1.5-liter transparent plastic bottle containing $96 \%$ alcohol to clean the chlorophyll in leaves so that parasitized and non-parasitized eggs in the leaf tissue can be seen more clearly (Figure 1). Infested leaves with leafhopper eggs were kept in the containers for 15 days in laboratory. Afterwards, leaves were boiled for 5-10 minutes in 5\% KOH solution to soften the hardened leaves [10]. The leaves samples were examined under illuminated binocular microscope and parasitized and nonparasitized eggs were counted (Figure 1)

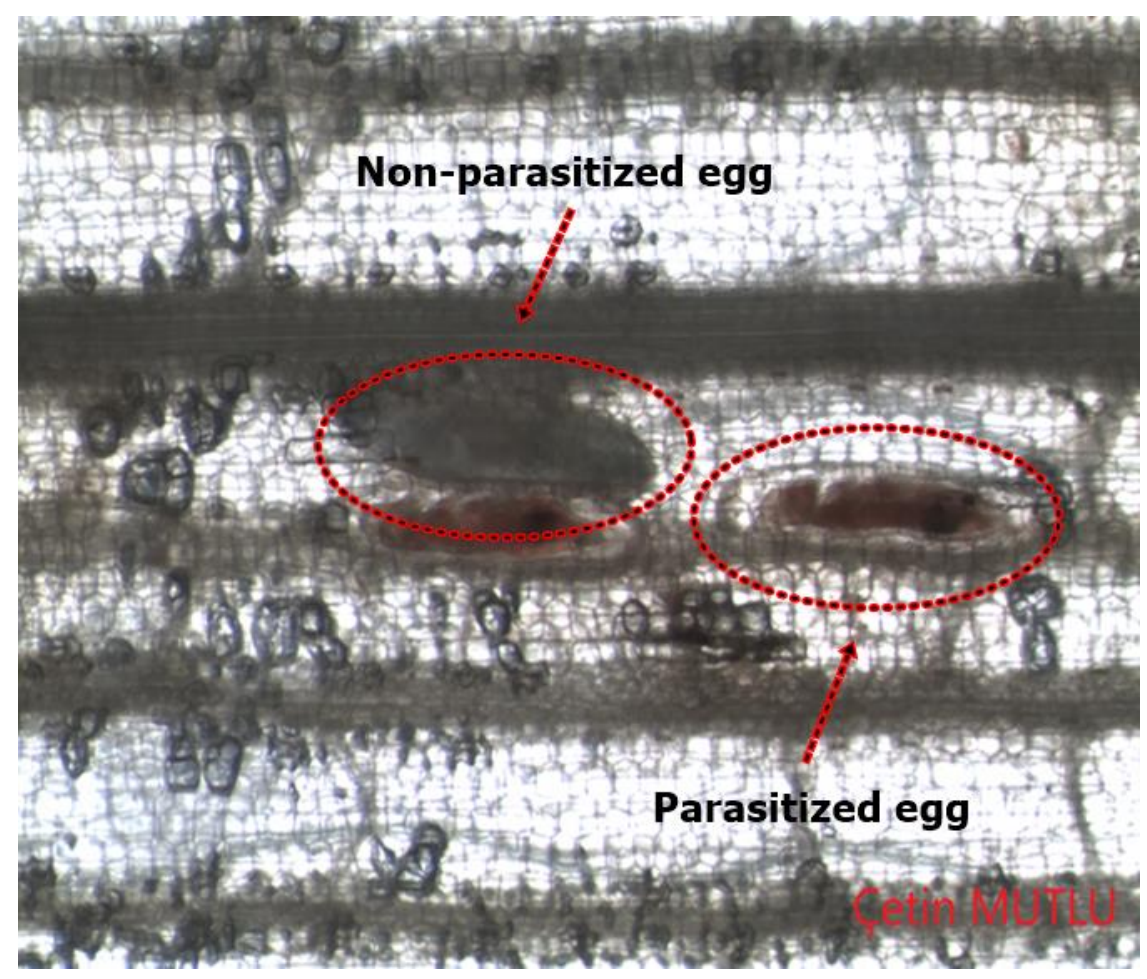

Figure 1 The parasitized and non-parasitized leafhoppers eggs inside maize leaf tissue

\subsection{Statistical analysis}

Data regarding density of leafhopper species in different districts were tested by paired $t$ test to observe the differences among districts. The analysis was repeated for each week. Data regarding the density of leafhopper species was visualized in Microsoft Excel to determine the peak infestation time. The data relating to weekly density of the studied leafhopper species and their egg parasitoid was presented and interpreted in the manuscript. All statistical computations were done on SPSS statistical software.

\section{Results}

\subsection{Population dynamic of leafhopper species and their egg parasitoid}

Significant variation was noted for the number of adults belonging to Z. sohrab, E. decipiens+ A. decedens and P. striatus trapped by yellow sticky traps (Figs 2-4).

Population density of different leafhopper species was significantly altered by individual and interactive effects of weeks, locations and species (Table 1). 
Table 1 Analysis of variance for different weeks, locations and species for population density of leafhopper species

\begin{tabular}{|l|c|c|c|c|c|}
\hline Source & DF & Sum of squares & Mean squares & F value & P value \\
\hline Week (W) & 15 & 4357781.81 & 290518.79 & 86.86 & $<0.0001$ \\
\hline Location (L) & 2 & 57295.81 & 28647.91 & 8.56 & 0.000 \\
\hline Species (S) & 2 & 11562670.84 & 5781335.42 & 1728.43 & $<0.0001$ \\
\hline $\mathrm{W} \times \mathrm{L}$ & 30 & 761393.15 & 25379.77 & 7.59 & $<0.0001$ \\
\hline $\mathrm{W} \times \mathrm{S}$ & 30 & 6456369.90 & 215212.33 & 64.34 & $<0.0001$ \\
\hline $\mathrm{L} \times \mathrm{S}$ & 4 & 445674.41 & 111418.60 & 33.31 & $<0.0001$ \\
\hline $\mathrm{W} \times \mathrm{L} \times \mathrm{S}$ & 60 & 1013019.52 & 16883.66 & 5.05 & $<0.0001$ \\
\hline
\end{tabular}

Bold values in the $\mathrm{p}$ value column indicate that relevant explanatory variable significantly altered dependent variable

Population dynamics of $Z$. sohrab monitored by yellow sticky traps is given in Fig. 2. The highest number of adults of $Z$. sohrab were recorded/trapped in Akçakale district compared to the rest of the locations included in the study. The highest population density of $Z$. sohrab was recorded at 2-4 leaf stage of maize during early August. Population density of $Z$. sohrab observed a sharp increase from late August when maize in ten leaf stage and reached to the highest level at the end of September. Afterwards, the population density started decreasing; however, significant number of $Z$. sohrab were still caught by these traps. The number of individuals were quite low during the middle of November. Although number of $Z$. sohrab individual's trapped varied among districts, population dynamics coincided for all locations according to the vegetation period of maize crop.

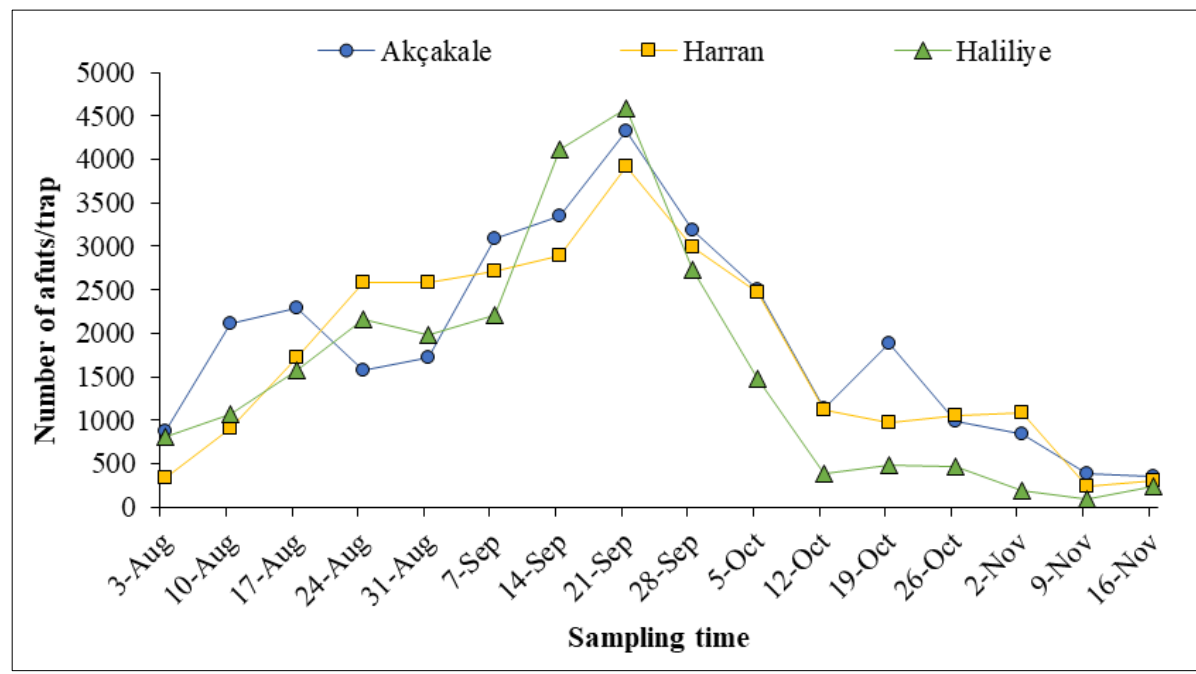

Figure 2 Population dynamics of Zyginida sohrab monitored by yellow sticky traps in three districts of Şanlıurfa province, Turkey

The highest density of Empoasca decipiens + A.decedens population was recorded during early August in Haliliye and Akçakale districts (2184 and 1216 adults/trap, respectively) compared to Harran district (336 adults/trap) (Fig. 3). Population of these leafhoppers increased in middle of August and reached to the highest level (1216 adults/trap) during generative stage of maize crop in Haliliye district. The population fluctuated between September and October when maize reached to maturity. Population density of these leafhoppers started to decrease during middle of October in all districts when maize leaves reached senescence.

Population density of $P$. striatus was quite low during early vegetation period of maize Haliliye, Akçakale and Harran districts (192, 184, 88 adults/trap, respectively) and no significant fluctuations was noted in the population density during the vegetation period of maize (Figure 4). Population density reached to the highest level during tasselig and maturation stages (496 adult/trap in Haliliye) of maize crop at the end of September. Psammottetix striatus abundance declined between October and November. 


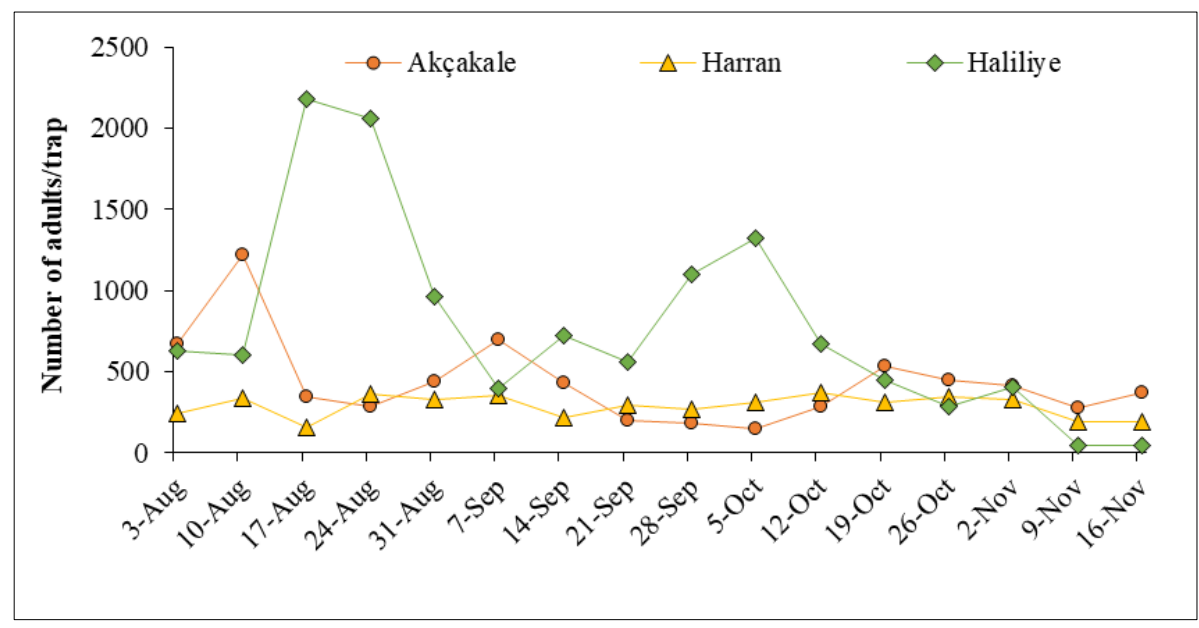

Figure 3 Population dynamics of Empoasca decipiens + Assymetrasca decedens monitored by yellow sticky traps in three districts of Şanlıurfa province, Turkey

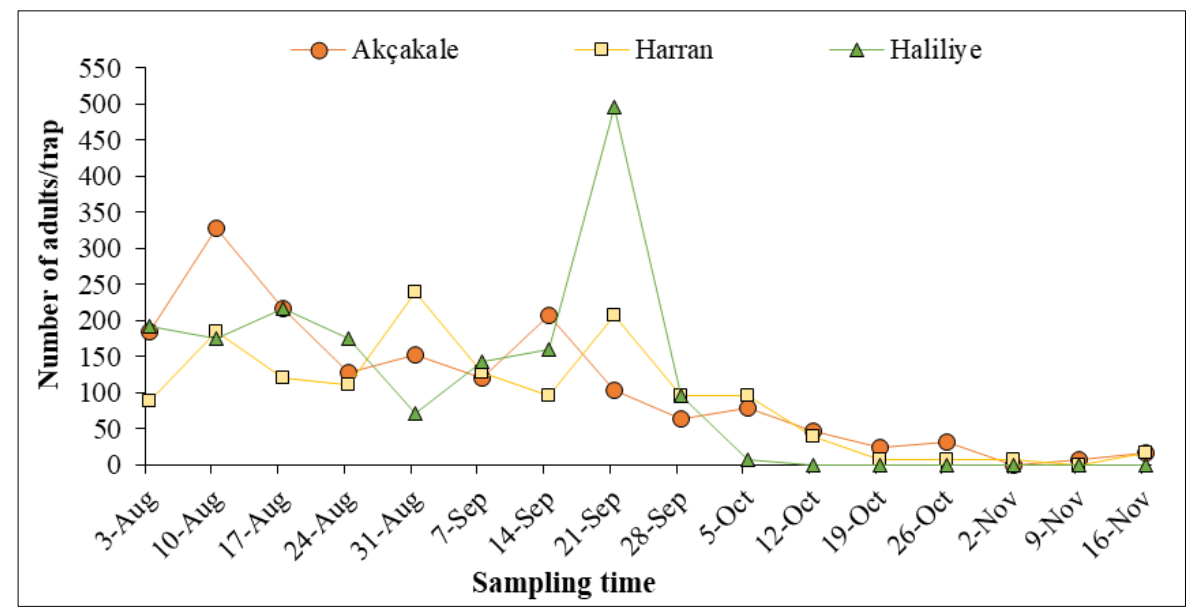

Figure 4 Population dynamics of Psammottetix striatus monitored by yellow sticky traps in three districts of Şanlıurfaprovince, Turkey

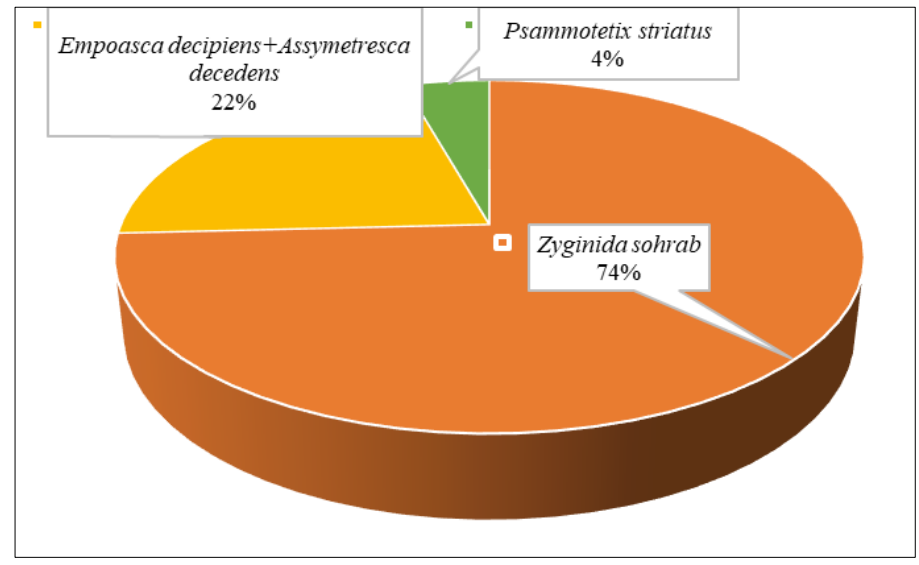

Figure 5 Relative occurrence of four leafhopper species in second crop maize cultivated in three districts of Şanlıurfa province 
Zyginida sohrab was the most dominated species in second crop maize grown in Şanlıurfa province, which was followed $A$. decedens+ E. decipiens. The lowest relative occurrence was recorded for P. striatus (Figure 5).

One mymarid parasitoid species, i.e., A. atomus was trapped by yellow sticky traps at all study locations during the whole vegetation period of maize crop. Population dynamics of parasitoid species coincided with the leafhopper species (Fig. 6). Population density of the parasitoid species increased until the first week of September at all locations. The population density of $A$. atomus reached to the highest level in middle September in all districts included in the study. Thereafter, population destiny of the parasitoid species dropped and remained low until end of the season.

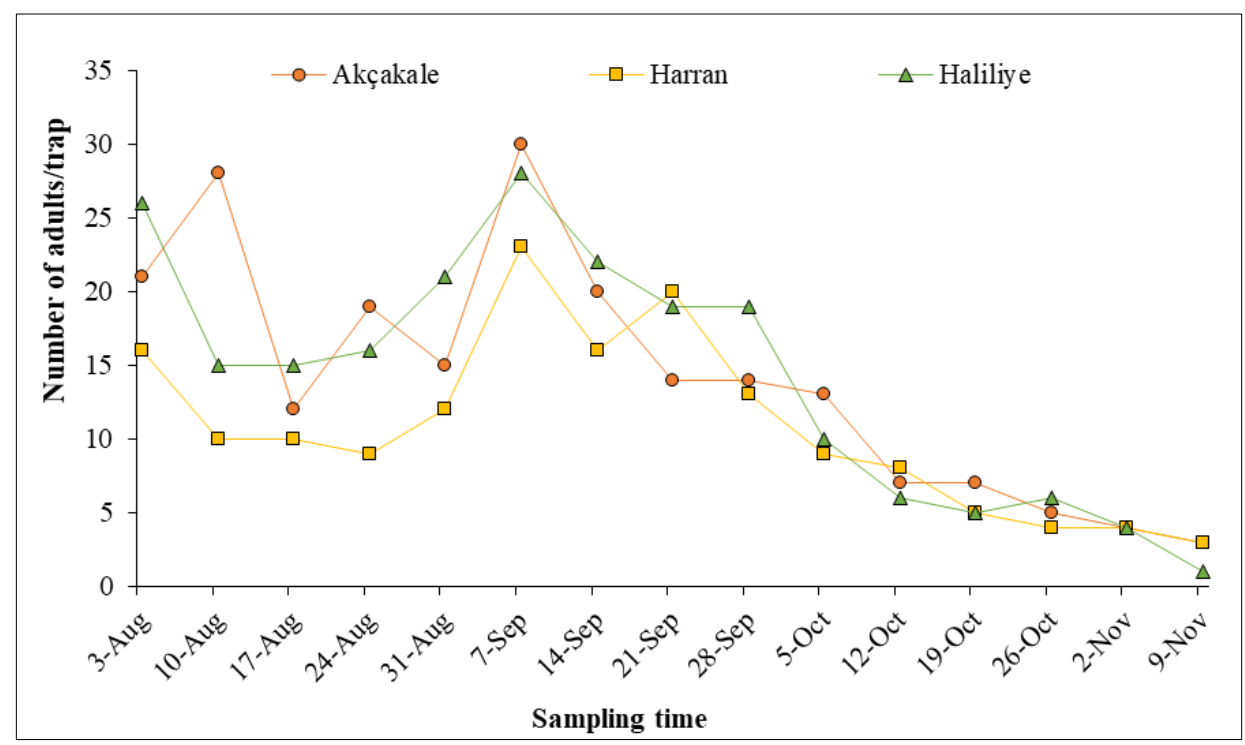

Figure 6 Population dynamics of Anagrus atomus monitored by yellow sticky traps in three districts of Şanlıurfa province, Turkey

\subsection{Parasitism rate of}

The average parasitism rate of in A. atomus Akçakale, Harran and Haliliye districts was 56.6, 57,8 and 59.5\%, respectively (Fig. 7). The parasitism initiated during first week of August and witnessed a continuous increase till first week of November. Although slight changes were observed in the parasitism rate, overall increased till last sampling time. The peak parasitism rate in Akçakale, Harran and Haliliye was 76.5, 84.2 and 76.4\%, respectively.

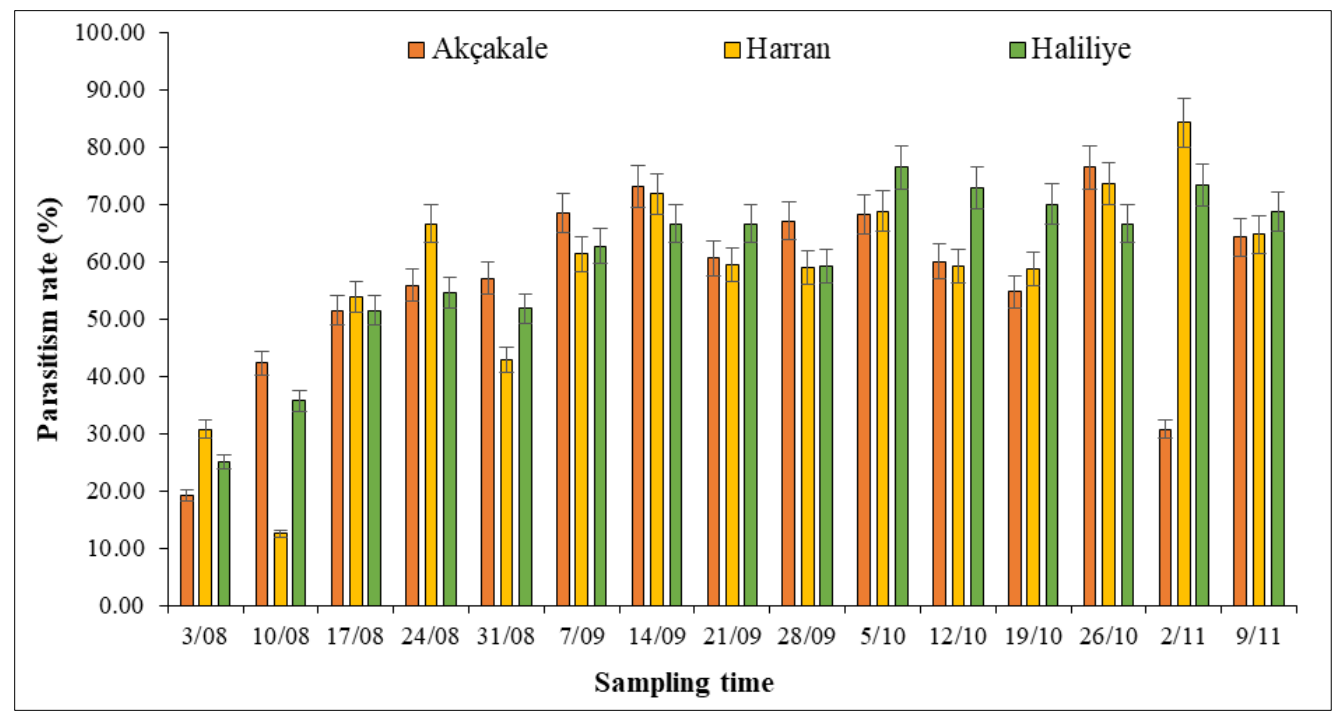

Figure 7 Parasitism rate of Anagrus atomus in three districts of Şanlıurfa province, Turkey 


\section{Discussion}

Population density of studied leafhopper species significantly varied among studied districts, as hypothesized (Table 1). The differences among studied districts are owed to the varying climatic conditions as well as slight changes in the vegetation period of maize. The other major deriver of the changes in population dynamics is the varying weed infestation in the maize fields in different districts. The studied leafhopper species, being polyphagous, infest numerous weed species [6]. Higher weed infestation either within the field or along the field edges significantly affect population dynamics of studied leafhopper species $[7,8,10]$.

The yellow stick traps attracted egg parasitoid of leafhopper species; however, the density of the parasitoid was extremely low compared to the density of the leafhopper species. This did not support our second hypothesis that the used traps significantly attract parasitoid species. This can be explained with the fact that pesticides are extensively used for pest management in second crop maize grown in southeastern Anatolia, which probably suppress the population of parasitoid species. However, no such data is available to support this inference.

Population dynamics of leafhopper species observed an initial increase in the density, reached to the peak and then declined. This is the particular behavior of insect species where they increase their density, damage the crop and then generation is terminated. The peak density coincided with the damage timing of the studied leafhopper species in maize crop. Hence, management strategies against the leafhopper species must be opted when their population density observed increase. Nonetheless, economic threshold value of these insects must be considered through regular pest scouting to avoid significant damages. Yilmaz and Karsavuran (2010) reported that population density of $A$. decedens reached to the highest level during the maturation period of maize crop and after this period, decreasing temperature forces the plants to enter senescence period and plant tissues get hardened [30]. Furthermore, irrigation is stopped after the crop matures, which leads towards the senescence of maize and weed plants. Due to these reasons, population density of leafhoppers decreases near to the harvest period of maize. Mutlu (2008) also reported that decrease in the population density of leafhoppers is linked with the senescence of weed species within and edges of maize fields [6].

The population density of $P$. striatus reached to the highest level during 2-4 leaves sage of maize crop in two districts of Diyarbakır province in Turkey. Population density of $P$. striatus decreased rapidly in the second crop maize during the generative period, and the number of individuals decreased to almost zero during maturation period [6]. The highest density of the species was recorded during tillering period of maize crop in a survey study conducted Çüngüş district of Diyarbakır province [3]. Göçmen et al. (1996) reported that individuals of this species feed on cotton and then shift to another crop [31]. Therefore, it is thought that $P$. striatus individuals transitioned from cotton fields adjacent to the studied maize fields and they continued to feed on young leaves of maize crop and complete their last progeny [6].

Parasitism rate on the leafhopper species was quite low than other studies conducted in southeastern Anatolia region, Turkey. The reasons of low parasitism are extensive use of pesticides on cotton as well as maize crops in Şanlıurfa province. Şanlıurfa is the largest cotton production zone of Turkey [1] and extensive pesticides are used to manage the insect pests of the crop (field observations). However, there is no study relating to impact of pesticide use on beneficial insects/parasitoids on maize. In a study conducted in Diyarbakir province (Bismil and Silvan districts) during 2012, parasitism rates of $A$. anagrus for $Z$. sohrab in second crop was 83.5-86.5\% [9]. Higher parasitism rate reported in this study compared to those obtained in the current study can be owed to higher pesticides' use in Şanlıurfa than Diyarbakır. This shows that excessive pesticide use suppresses the population of beneficial insects in maize. In another study, Mckenzie (1973) reported that parasitism rate of the harmful leafhopper Erythroneura ziczac Walsh by A. epos in vineyards of Canada ranged between 21-87\% throughout the season [32]. Meyerdirk and Hessein (1985) conducted a study in southern California to observe population dynamics and parasitism rate of $C$. tenellus and Empoasca s. in sugar beet crop [33]. These species were Anagrus giraulti Crawford, Polynema sp., Gonatoeerus sp. (Mymaridae), Paraeentobia sp. ve Aphelinoidea sp. (Trichogrammatidae) and parasitism rate was 81\%. Vidano and Arzone (1985) concluded that Z. pullula should not be considered as a serious pest of cereals in Italy, since its eggs are effectively parasitized by $A$. atomus, despite its intensive feeding and migration capacity [34]. Yiğit and Erkılıç (1987) reported that 0 . pallida and $A$. atomus parasitize $85-99 \%$ eggs of harmful vineyard pest, i.e., A. adanae in southern Anatolia Region of $85-99 \%$ due to which chemical control was not required [35].

Anagrus atomus parasitizes the eggs of E. vitis causing 90\% mortality of the pest [21]. Gladstone et al. (1996) reported that Anagrus sp. and Paracentrobia sp. parasitized D. maidis [36]. Sutre and Fos (1997) reported that A. atomus was the most effective natural enemy of harmful E. vitis in vineyards in France [37]. In another study, it was determined parasitism rate of $A$. atomus on E. decipiens in four bean cultivars was $24.34 \%$ in Iran during 2004 and $33.33 \%$ during 2005 [38]. Bayoun et al. (2008) determined that C. tenellus was parasitized by A. nigriventris the USA [39] and E. vitis 
was parasitized by A. atomus at a rate of $29-52.7 \%$ in the vineyard areas in Italy [40]. These studies have shown once again that Anagrus atomus was very important egg parasitoids on harmful leafhoppers.

\section{Conclusion}

In order to suppress the population of harmful leafhopper species in second crop maize fields and to increase the effectiveness of parasitoid of $A$. atomus, which is important in natural biological control. It is necessary to minimize the chemical control and pay attention to the specific effectiveness of the pesticides to be used.

\section{Compliance with ethical standards}

\section{Acknowledgments}

This study was produced the part of master thesis and supported by Harran University, Scientific Research Projects Commission, and HÜBAK Project No: 19037. The authors gratefully acknowledge supporting the study.

\section{Disclosure of conflict of interest}

No conflict of interest. The authors declare that there is no conflict of interests regarding the publication of this paper. Study design: C..M and M.M. Field study: A.T. Data analysis: C..M. Drafting the manuscript: C..M.

\section{References}

[1] TUIK. Turkish statistical Institute, Data portal for statistic. 2020.

[2] Gözüaçık C, Mart C. The studies on determination of lepidopterans pest and their densities and distributions in maize fields in Southeast Anatolia. Harran University Journal of the Faculty of Agriculture. 2005; 9(4): 11-16.

[3] Şimşek Z. Studies on the Insect Species Harmful on Corn and Sorghum, Their Determination and Distribution in Eastern and Southeastern Anatolia Regions in Turkey. Diyarbakir Plant Protection Research Institute Publication. 1988; 6: 86.

[4] Alaoğlu Ö, Ercan B, Sade B, Soylu S, Öztemiz S, Palta Ç, Güneş A, Uysal M, Fidan H. The population development and density of Zyginidia sohrab Zachvatkin (Hemiptera: Cicadellidae) and its effects on yield and yield components in maize (Zea mays L.). Journal of Crop Research. 2007; (1): 1-7.

[5] Ercan B, Uysal M. Zygnidia sohrab Zatcvatkin (Cicadellidae) as an important maize pest in Konya province and its population dynamics. Proceedings of the Second Plant Protection Congress of Turkey. 2007; 55.

[6] Mutlu Ç, Sertkaya E, Güçlü Ş. The population fluctuations of Cicadellidae (Homoptera) species on second crop maize in Diyarbakır province. Turkish Journal of Entomology. 2008; 32(1): 21-32.

[7] Mutlu Ç, Sertkaya E, Güçlü Ş. Determination of Cicadellidae (Homoptera) species in second crop maize and their distribution in Diyarbakır province of Turkey. Turkish Journal of Entomology. 2008; 32(4): 281-301.

[8] Mutlu Ç, Sertkaya E. Studies on Bio-ecology of Zyginidia sohrab Zachvatkin (Hemiptera: Cicadellidae), harmful leafhopper on maize plant in Diyarbakir Province. Plant Protection Bulletin. 2015; 55(1):15-30.

[9] Mutlu Ç, Sertkaya E. The parasitization rates on some harmful leafhoppers on maize of the egg parasitoid, Anagrus atomus (Hymenoptera: Mymaridae). Turkish Journal of Biological Control. 2015; 6(1): 25-40.

[10] Mutlu Ç, Sertkaya E. Biology of the leafhopper, Zyginidia sohrab Zachvatkin, on corn under laboratory conditions. Journal of Entomology and Zoology Studies. 2016; 4(4): 401-406.

[11] Akmeșe V, Sertakaya E. Determination of Cicadellidae (Hemiptera) species in the maize fields in Eastern Mediterranean region of Turkey. Mustafa Kemal University Journal of Agricultural Sciences. 2020; 26 (2):497505.

[12] Zhao L, Dai W, Zhang C, Zhang Y. Morphological characterization of the mouthparts of the vector leafhopper Psammotettix striatus (L.) (Hemiptera: Cicadellidae). Micron. 2010; 41(7): 754-759.

[13] A DR, Wei NS, Zhang QF, Zhang R, Zhu XS. The first report to wheat mycoplasma like-organism blue dwarf disease (WMBD). Acta Phytopathologica Sinica. 1991; 21: 263-266. 
[14] Abou-Jawdah Y, Abdel Sater A, Jawhari M, Sobh H, Abdul-Nour H, Bianco PA, Alma A. Asymmetrasca decedens (Cicadellidae, Typhlocybinae), a natural vector of 'Candidatus Phytoplasma phoenicium'. Annals of Alied Biology. 2014; 165(3): 395-403.

[15] Backus EA, Serrano MS, Ranger CM. Mechanisms of hopperburn: an overview of insect taxonomy, behavior, and physiology. Annual Review of Entomology. 2005; 50: 125-151.

[16] Ersin F, Yilmaz E, Kaya E, İlker E, Turanli F. Determination of Damage and Economic Injury Level of Zyginidia pullula (Boheman, 1845) (Hemiptera: Cicadellidae) on Second Crop Corn in Aegean Region. Journal of Agricultural Faculty of Ege University. 2017; 54 (3): 285-292.

[17] Arno C, Alma A, Arzone A. Anagrus atomus as Egg Parasite of Typhlocybinae (Rhynchota, Auchonorrhyncha). In:Proceedings of the 6th Auchenorrhyncha Meeting, 7-11 September 1987;Turin, Italy. 1987; 611-615.

[18] Böll S, Herrmann JV. A long-term study on the population dynamics of the grape leafhopper (Empoasca vitis) and antagonistic mymarid species. Journal of Pest Science. 2004; 77(1): 33-42.

[19] Hesami S, Seydoselami H, Ebadi R. Biology of Anagrus atomus (Hymenoptera:Mymaridae), an Egg Parasitoid of the Grape Leafhopper Arboridia kermanshah (Homoptera:Cicadellidae) Entomological Science. 2004; 7: $271-276$.

[20] Vidano C, Arno C, Alma A. On the Empoasca vitis İntervention Threshold on Vine (Rhynchota, Auchenorrhyncha). In:Vidano, C. \& Arzone, A.(eds.), Proceedings of the 6th Auchenorrhynchy Meeting, CNR-OPRA, Torino. 1987; 525537.

[21] Cerutti F, Baumgartner J, Delucchi V. Research on the Grapevine Ecosystem in Tessin: III.Biology and Mortality Factors Affecting Empoasca vitis Goethe (Homoptera, Cicadellidae, Typhlocybinae). Mitteilungen der Schweizerischen Entomologischen Gesellschaft. 1990; 63(1-2): 43-54.

[22] Atakan E, Canhilal R. Evaluation of yellow sticky traps at various heights for monitoring cotton insect pests. Journal of Agricultural and Urban Entomology. 2004; 21: 15-24.

[23] Matsukura K, Yoshida K, Matsumura M. Efficient monitoring of maize orange leafhopper, Cicadulina bipunctata (Hemiptera: Cicadellidae), and small brown planthoer, Laodelphax striatellus (Hemiptera: Delphacidae), in forage maize fields using yellow sticky traps. Alied entomology and zoology. 2011; 6(4): 585-591.

[24] Speight MR, Hunter MD, Watt AD. Insect pest management. In: Speight MR, Hunter MD, Watt AD (eds) Ecology of insects. Blackwell, Oxford. 2008; 429-513.

[25] DeGooyer TA, Pedigo LP, Rice ME. Development of sticky trap sampling technique for potato leafhopper adult. Journal of Agricultural Entomology. 1998; 15: 33-37.

[26] Lessio F, Alma A. Seasonal and daily movement of Scaphoideus titanus Ball (Homoptera: Cicadellidae). Environmental Entomology. 2004; 33(6): 1689-1694.

[27] Demirel N, Yıldırım AE. Attraction of various sticky color traps to Thrips tabaci Lindeman (Thysanoptera: Thripidae) and Empoasca decipiens Paoli (Homoptera: Cicadellidae) in cotton. Journal of Entomology. 2008; 5: 389-394.

[28] Özgen İ, Bolu H, Ayaz T, Koç İ, Mutlu Ç, Altun AA. Determining the Efficiency of Mass Trapping of Yellow Sticky Traps in Different Wavelengths against Pistachio Psyllid in Siirt Province [Agonescena pistaciae Burc. and Laut. (Hemiptera: Psyllidae)]. International Journal of Innovative Engineering Alications. 2020; 4(1): 20-30.

[29] Bilgili AV, Yeşilnacar İ, Akihiko K, Nagano T, Aydemir A, Hızlı HS, Bilgili A. Post-irrigation degradation of land and environmental resources in the Harran plain, southeastern Turkey. Environmental monitoring and assessment. 2018; $190(11): 1-14$.

[30] Yılmaz E, KarsavuranY. The population fluctuations of Asymmetrasca decedens (Paoli, 1932) and Zyginidia pullula (Boheman, 1845) (Homoptera: Cicadellidae) in maize fields in Izmir. Turkish Journal of Entomology. 2010; 34(2): 241-250.

[31] Göçmen H, Güçlü Ş, Dağli S. Cicadellidae species and their population fluctuations on cotton in Antalya. Proceedings of the Third Turkish National Congress of Entomology, 24-28 September, Ankara. 1996; 23-29.

[32] Mckenzie LM. The grape leafhopper, Erythroneura ziczac (Homoptera: Cicadellidae), and its Mymarid (Hymenoptera) egg-parasite in the Okanagan Valley, British Columbia. The Canadian Entomologist. $1973 ; 104$ (8): 1229-1233. 
[33] Meyerdirk DE, Hessein, NA. Population Dynamics of the Beet Leafhopper, Circulifer tenellus (Baker), and Associated Empoasca s. (Homoptera: Cicadellidae) and Their Egg Parasitoids on Sugar Beets in Southern California. Journal of Economic Entomology. 1985; 78: 346-353.

[34] Vidano C, Arzone A. Zyginidia pullula: distribution over the territory and biological cycles. Redia. 1985; 68: 135150.

[35] Yiğit A, Erkılıç L. Studies on distribution, biology and pest status of grape leafhopper Arboridia adanae Dlab. (Homoptera: Cicadellidae) in Southern Anatolia, Turkey. Proceedings of the First Turkish National Congress of Entomology, 13-16 October, İzmir. 1987; 25-34.

[36] Gladstone SM, Liana A, Rios R, Lopez L. Egg Parasitoids of the Corn Leafhopper, Dalbulus maidis (DeLong and Wolcott) (Homoptera: Cicadellidae) in Nicaraguan Maize. Proceedings of the Entomological Society of Washington. 1996; 96(1): 143-146.

[37] Sutre B, Fos A. Anagrus atomus, natural parasitoid of leafhoppers. Preliminary efficiency test in vineyards. Phytoma. 1997; 49(495): 40-44.

[38] Fathipour N, Talebi AA. Seasonal Parasitism of Empoasca Decipiens by Anagrus atomus On Four Bean Species in Tehran Area. Alied Entomology and Phytopathology. September 2007; 75(1): 1-11.

[39] Bayoun IM, Walker GP, Triapitsyn SV. Parasitization of Beet Leafhopper Eggs, Circulifer tenellus,in California. Journal of Alied Entomology. 2008; 132: 412-424.

[40] Pavan F, Picotti P. Influence of Gapevine Qultivars on the Leafhopper Empoasca vitis and its Egg Parasitoids. Bio Control. 2009; 54: 55-63. 